\title{
Editorial
}

\section{Why place branding is not about logos and slogans}

Place Branding and Public Diplomacy (2013) 9, 71-75. doi:10.1057/pb.2013.11

Many authors in this journal and commentators elsewhere have repeatedly claimed the relative insignificance of logos and slogans in place branding. Yet, many practitioners and policymakers continue to spend time, money and effort on them. Maybe there are good reasons why logos and slogans are popular and some of these arguments will be addressed in this editorial. However, for those of us that look beneath the surface, it seems rather obvious that the contribution that logos and slogans can make to the management of places as brands is rather limited. Even though this relative irrelevance of logos and slogans in place branding is asserted often in the literature, the arguments for that claim are generally omitted or 'lost in translation'. Maybe that is why the practice of place branding continues the logo fetish and hence it might be useful to bring the arguments against the importance of logos and slogans together again, here. The reason why this is important is not just because of the potential misuse of taxpayers money, but also because logos and slogans seem to be ascribed with powers that they do not possess, diverting focus, resources and effort from what actually is important in place branding.

Branding is about reputation management, or, more specifically, about managing brand equity. Even in this journal, it is very popular to use the definition of brand as supplied by the American Marketing Association (1995): 'A brand is a name, term, design, symbol, or any other feature that identifies one seller's good or service as distinct from those of other sellers'.
From this, many policymakers, practitioners and even some commentators distil that place branding is about designing logos and slogans for places, while forgetting that the essence of it is to make something identifiable as distinctive. The name or logo is the tool for identification and recognition, but the core of branding is to make sure that consumers attach distinctive associations to this entity (building reputation). In other words, a trademark only becomes a brand when it is recognised and represents meaning to external audiences. As places already have (more often than not meaningful) names and landmarks, the amount of time and investment generally spent on designing logos and slogans as opposed to actual reputation management for places, seems to be a waste.

In commercial branding, logos, slogans and design are relatively important for consumers to recognise brands in a retail environment where quick purchase decisions are required. However, one does not find places offering their 'services' in the supermarket (Anholt, 2010). Hence, the focus should not be on branding providing means for recognition, but on managing distinctive image associations. On the basis of Aaker (2001) and Aaker and Joachimsthaler (2000), place brands have been defined as 'representations of place identity, building a favourable internal (public, private and civil society stakeholders) and external (tourists, investors, traders, migrants) image', leading to brand equity; that is, brand satisfaction and loyalty; name awareness; perceived quality; and other favourable brand associations 
(that is, positive image and reputation) attached to a name or symbol representing a country, city or region (Govers and Go, 2009, p. 17). In commercial branding, a logo can assist in brand recognition and in creating awareness, by visualising a brand through attractive design, in addition to the name of the entity that is represented. This is particularly of importance to new businesses and products or services that have no recognition at all and for whom the most important decision is the choice of name for their business, possibly supported by a particular typeface, logo and/or slogan, and trademark protection. However, most places already have names to which audiences attach meaning (be it globally for major countries and cities, or regionally for others, depending on geographical catchment area), so why bother with a logo?

A useful illustration of the irrelevance of this can be found where one would not expect it; the music industry. The artist Prince, after building a very strong global presence and reputation, 15 years into his career, after 14 albums, 10 world tours, 4 movies, numerous Grammy and MTV Music Award nominations and 8 wins, decided in 1993 not to use the stage name Prince anymore, but use the 'Love Symbol' (q) instead. As the symbol had no stated pronunciation, Prince was often referred to as 'The Artist Formerly Known as Prince', as well as 'The Artist'. Did this improve his reputation? Arguably it even damaged audience awareness of the artist as it left fans confused as to how to refer to their idol, leading to a decision in the year 2000 to return to the use of the name Prince as soon as his publishing contract with his former record label expired. Interestingly, the name changes also involved trademark issues and legal battles with record labels; that is, protection issues that are equally relevant in the choice of name and symbol for commercial businesses. However, these are issue that do not apply in the context of place names, the use of which cannot be protected. Something places can do for the logo they use, but then again, there are so many ways in which places interact with publics; it is hard to imagine that controlling use of a logo will make much of a difference in the way that places generate awareness and build their reputation.
In fact, that brings us to another argument why logos and slogans are relatively unimportant in place branding. In commercial branding, visual identity is often linked to a specific product or service and the set of associations that consumers have in their minds is rather limited. Corporate branding might be a better discipline to inform place branding, but even then the engagement with consumers is often limited to corporate communications strategies and product use (in which brand recognition through logos and design is therefore crucial). For the sake of argument, take the 2012 top-20 global brands according to Forbes (Badenhausen, 2012), most of which are corporate brands, logically, considering their size. Apple, Microsoft, Coca-Cola, IBM, Google, Intel, McDonalds, General Electric, BMW, Cisco, Oracle, Samsung, Disney, Toyota, HewlettPackard, Mercedes-Benz, Louis Vuitton, Gillette, Honda and Nescafe are all clearly linked to product categories and most of what we all have learned about them is through product use and corporate marketing communications. Maybe, the exception here is Disney, which purely sells hedonic products (the consumption of which is an end in itself; that is, enjoyment of movies, theme parks, toys and so on); the production of fantasies that have an impact on our lives beyond conventional consumer value (for example, utility, convenience and status). For most brands, it is not surprising that any other opportunity to engage with audiences through others means than marketing can occasionally be of significant importance. For example, consider the impact that business leaders with celebrity status can have on a brand, such as Sir Richard Branson's impact on the brand Virgin; Bill Gates on Microsoft or Steve Jobs' making of Apple. The ways in which commercial brands interact with international publics are just relatively limited and hence controllable.

Places, on the other hand, are much more complex. Often, the mistake is made to treat the city or region as product, which they are not. Places offer environments that allow for product offerings to be brought to international markets; such as tourism product market combinations, investment opportunities, exported goods, cultural 
offerings, employment and housing opportunities or international study programme offerings. It clearly shows that places are not even active in any particular industry exclusively and besides an environment for economic activities, places are spaces where people live, in which they move around, bring up their children, enjoy their work and leisure time, become ill and hopefully get treated in a well-organised healthcare system, are engaged in social, sport and cultural activities in associations and NGOs. To think that the awareness and reputation of all this can be influences by the use of a logo or slogan seems to be rather naïve, to put it mildly.

There are various 'image formation agents' (Gartner, 1993) that influence the way that people understand the world. The most important agents that form perceptions in peoples' minds are, of course, their own experiences (also referred to as organic agents), followed by word of mouth about the experiences of peers, friends, relatives or otherwise networked contacts (call them social agents). Other important sources of information are provided by mass media, referred to as autonomous agents (see two papers on media impact in this edition). Only last in this line of agents vying for attention are the induced agents; marketing communications messages with commercial intent. People are least receptive to these latter kinds of agents (Govers and Go, 2009). Most commercial brands depend mostly on organic and induced agents, which generally can be controlled by design. Carefully planned product use, retail environments or flagship stores manipulate organic agents and ingenious integrated marketing communications control induced agents. Visual identity, including logos and slogans, can have a significant impact on recognition and brand equity in these circumstances. At the same time, social and autonomous agents do not tend to be as important for most commercial brands. Logically, people are inclined to share more intense stories about their hedonic consumption experiences (their travels, the books they read or that movie that they saw) as opposed to the utilitarian goods they use (their vacuum cleaner, toothpaste or the soft drinks they like). Notice that these hedonic goods are often linked to place (see also Michael Chattalas and Hirokazu Takada's paper on this in this edition). Besides, the complexity of places allows for even more intense interaction and engagement and it is not surprising that social media have turned place marketing activities on their heads. Moreover, places receive much more attention and on a wider range of topics and issues than corporations and product offerings do (in fact, most media are wary of messages that potentially have a commercial impact; they do their own agenda setting as Rajul Jain shows in this edition). Hence, it seems rather obvious that control over image formation agents for places is much more complex and cannot be manipulated by 'weak instruments' such as logos and slogans.

Finally, places are under political pressure and consist of contested identities, so to summarise them in a simple logo and slogan can be highly controversial and often leads to very bleak concepts as a result of applying common denominators. There are even cases of public uprising, where residents reject the 'branding' initiatives of their elected representatives and it is not surprising. In the context of the 'Branding Smallville' paper by Jay Sang Ryu and Jane Swinney in this edition, it is relevant to mention that in the United States initiatives in Coral Springs (Everything under the sun), McKinney, TX (Unique by nature), Brookings, SD (Bring your dreams), Columbus, Ind. (Unexpected. Unforgettable.) and Florida (The perfect climate for business) received criticism (Mayo, 2013). So did the cities of Aarhus (The modern knowledge city), Karlstad (with a smiling sun as its logo, underlining its sunny position and disposition), Manchester (A mature city), Lyon (Only Lyon) or Munich (Munich loves you) in Europe (Govers and Baker, 2011). By the way, Tbilisi, Georgia also 'loves you', as some other places probably do as well.

Does all that mean that logos and taglines in place branding are completely useless? No they are not necessary and obviously, as the reality out there shows, there is a market for it. It seems that in the minds of policymakers there is a space for the use of design as a way to represent geographical entities and it also seems obvious that it is something that is easy to buy. What this has done, 
in some cases, is to facilitate professionalism. If all government agencies (and maybe even some private and civil society actors) use the same design in their stationary and the way they present themselves, consistency can project a professional image (Anholt, 2010). Logos and slogans can also generate momentum in raising awareness. If local businesses, multinationals with provenance, diplomatic actors, cultural organisations, exporters, tourism businesses, promotion boards, government agencies and individuals, consistently engage with the outside world referencing their origin with pride, it will raise awareness and may even have a slight impact on reputation. However, such support and momentum will not be achieved without a clear sense of what the brand is supposed to represent and propel. Therefore, again, it is strategy and substance first, then the rest (Anholt, 2008). Unfortunately, the practice of place branding often works the other way around, if they get to work on brand strategy at all. Oftentimes, logos and slogans are introduced without any idea about what they mean or what intended equity they are to build, as the examples above show. In such cases, generally, engagement is lacking, the visual identity is just something that goes in the corner of the page on stationary, business cards and flags and hence the initiative is extremely limited in its effect.

Therefore, Governments often wonder how they can enforce the use of their 'brand' (that is, logo) and regulate who can and who cannot carry it and in what way. It is the wrong question to ask and asking it is recognition of defeat. A good brand strategy not only builds engagement with the outside world, but also among stakeholders and internal audiences. It should be built on a sense of belonging and shared purpose and hence generate the kind of engagement that is desired and impossible to imitate elsewhere. By achieving that, internal stakeholders should be self-motivated to join the game and not forced. This is how 'I $\mathbf{v N Y}$ ' and 'I AMsterdam' became successful, not because they are clever design gimmicks (which they are), but because they represent something that people were already proud of or engaged with. Governments in New York City and Amsterdam did not need to strategise about what these logos were to represent and how to build awareness; the equity was already there in most peoples' minds, both in those of local stakeholders as well as global audiences. The logos just helped in creating something to characterise that equity (that is, a brand). In fact, 'I $\boldsymbol{\vee N Y}$ ' was designed in 1977 for a New York State tourism campaign, which was expected to last only a few months. Designer Milton Glaser did the work pro-bono. The logo got to be associated with the City of New York unintentionally and was reinvigorated after 9/11, when people started wearing it (in adapted form) for commemoration, creating a sense of unity (Kidd, 2003). Interestingly, Glaser is not worried about trademark infringement.

Unfortunately, most places do not have this luxury of a historically built global awareness and reputation and that is exactly why they want to do 'something with branding', thinking that 'I •...' will help them, but it will not (unbelievable so many places have actually tried specifically this 'I $\bullet . . . '$ - and failed). It is not the symbol that builds the reputation, but the symbol can become an icon for an existing reputation that has been painstakingly built over a period of time. Anholt (2010) makes the same observation for flags. Hence, we, as a community of scholars and informed practitioners, should beg those who are considering their own version of 'I $\boldsymbol{\bullet} .$. ' to not do it and others who think that, by designing giant letters or logos and moving them around their city, cities or towns for people to engage with, to please reconsider. Maybe the good old T-shirt rule of thumb should be kept in mind. If you write the name of the city, region or country in question on a T-shirt, will there be a commercially viable market of people willing to pay more than US $\$ 25$ for it? If the answer is yes, then maybe clever design gimmicks will generate engagement and have social media impact for your brand, but if not, start with strategy and substance first and take your time, lots of time.

\section{REFERENCES}

Aaker, D.A. (2001) Strategic Market Management. 6th edn. New York: John Wiley \& Sons. 
Aaker, D.A. and Joachimsthaler, E. (2000) Brand Leadership. New York: The Free Press.

American Marketing Association. (1995) Dictionary, http:// www.marketingpower.com/_layouts/Dictionary.aspx? dLetter=P, accessed 30 September 2011.

Anholt, S. (2008) Place branding: Is it marketing, or isn't it? Place Branding and Public Diplomacy 4(1): 1-6.

Anholt, S. (2010) Definitions of place branding - Working towards a resolution. Place Branding and Public Diplomacy 6(1): $1-10$

Badenhausen, K. (2012) The world's most powerful brands. Forbes, http://www.forbes.com/powerful-brands/, accessed 17 April 2013.

Gartner, W.C. (1993) Image formation process. Journal of Travel and Tourism Marketing 2(2/3): 191-215.

Govers, R. and Baker, B. (2011) EUROCITIES Branding Report is Obsessed with Logos and Slogans. CityMayors, http://www.citymayors.com/marketing/eurocitiesbranding-review.html, accessed 19 April 2013.

Govers, R. and Go, F.M. (2009) Place Branding: Glocal, Virtual and Physical, Identities Constructed, Imagined and Experienced. Basingstoke, UK: Palgrave Macmillan.

Kidd, C. (2003) Talks with Milton Glaser. The Believer, http:// www.believermag.com/issues/200309/?read=interview_ glaser, accessed 19 April 2013.

Mayo, M. (2013) City branding efforts seem a waste of good money. Sun Sentinel, http://www.sun-sentinel.com/news/ fl-city-slogans-mayocol-b031013-20130309,0,4499980. column, accessed 19 April 2013.

Robert Govers Independent advisor, scholar and author on Place Branding 